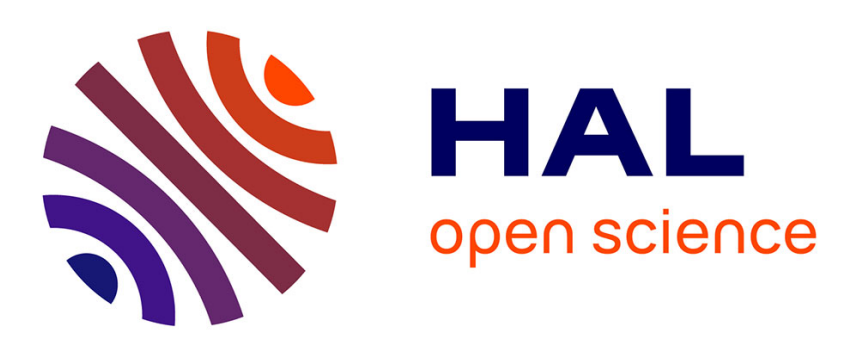

\title{
Modelling of trace metal transfer in a large river under different hydrological conditions (the Garonne River in southwest France)
}

Cyril Garneau, Sabine Sauvage, Anne Probst, Jose-Miguel Sanchez-Perez

\section{- To cite this version:}

Cyril Garneau, Sabine Sauvage, Anne Probst, Jose-Miguel Sanchez-Perez. Modelling of trace metal transfer in a large river under different hydrological conditions (the Garonne River in southwest France). Ecological Modelling, 2014, vol. 306, pp. 195-204. 10.1016/j.ecolmodel.2014.09.011 . hal01167062

\author{
HAL Id: hal-01167062 \\ https://hal.science/hal-01167062
}

Submitted on 23 Jun 2015

HAL is a multi-disciplinary open access archive for the deposit and dissemination of scientific research documents, whether they are published or not. The documents may come from teaching and research institutions in France or abroad, or from public or private research centers.
L'archive ouverte pluridisciplinaire HAL, est destinée au dépôt et à la diffusion de documents scientifiques de niveau recherche, publiés ou non, émanant des établissements d'enseignement et de recherche français ou étrangers, des laboratoires publics ou privés. 


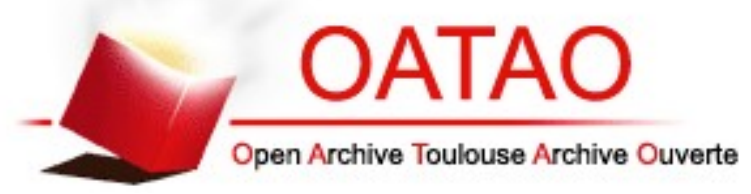

\section{Open Archive TOULOUSE Archive Ouverte (OATAO)}

OATAO is an open access repository that collects the work of Toulouse researchers and makes it freely available over the web where possible.

This is an author-deposited version published in : http://oatao.univ-toulouse.fr/ Eprints ID : 13937

To link to this article : DOI:10.1016/j.ecolmodel.2014.09.011

URL : http://dx.doi.org/10.1016/j.ecolmodel.2014.09.011

To cite this version : Garneau, Cyril and Sauvage, Sabine and Probst, Anne and Sanchez-Pérez, José-Miguel Modelling of trace metal transfer in a large river under different hydrological conditions (the Garonne River in southwest France). (2014) Ecological Modelling, vol. 306. pp. 195-204. ISSN 0304-3800

Any correspondance concerning this service should be sent to the repository administrator: staff-oatao@listes-diff.inp-toulouse.fr 


\title{
Modelling of trace metal transfer in a large river under different hydrological conditions (the Garonne River in southwest France)
}

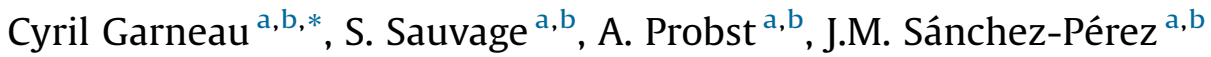 \\ a Université de Toulouse; INPT, UPS; EcoLab (Laboratoire écologie fonctionnelle et environnement), Ecole Nationale Supérieure Agronomique de Toulouse \\ (ENSAT), Castanet Tolosan, France \\ ${ }^{\mathrm{b}}$ CNRS; EcoLab (Laboratoire écologie fonctionnelle et environnement), Castanet Tolosan, France
}

\begin{abstract}
A B S T R A C T
The modelling of trace metals (TM) in rivers is highly dependent on hydrodynamics, the transport of suspended particulate matter (SPM) and the partition between dissolved and particulate phases. A mechanistic, dynamic and distributed model is proposed that describes the fate of trace metals in rivers with respect to hydrodynamics, river morphology, erosion-sedimentation processes and sorptiondesorption processes in order to identify the most meaningful parameters and processes involved at the reach scale of a large river. The hydraulic model is based on the 1-D Saint Venant equation integrating real transects to incorporate the river's morphology. The transport model of dissolved species and suspended sediments is based on advection-dispersion equations and is coupled to the one-dimensional transport with inflow and storage (OTIS) model, which takes transient storage zones into account. The erosion and sedimentation model uses Partheniades equations. Finally, the transfer of trace metals is simulated using two parameters, namely the partition coefficient (Kd) and the concentration of TM in the eroded material. The model was tested on the middle course of the Garonne River, southwest France, over an $80 \mathrm{~km}$ section under two contrasting hydrological conditions $\left(80 \mathrm{~m}^{3} \mathrm{~s}^{-1}\right.$ and $\left.800 \mathrm{~m}^{3} \mathrm{~s}^{-1}\right)$ based on measurements (hydrology, suspended sediments, particulate and dissolved metals fractions) taken at 13 sampling stations and tributaries. The hydrodynamic model was calibrated with discharge data for the hydraulic model, tracer experiments for the dissolved transport model and SPM data for the erosion-sedimentation model. The TM model was tested on two trace metals: arsenic and lead. Arsenic was chosen for its large dissolved fraction, while lead was chosen for its very important particulate fraction, thus providing contrasting elements. The modelling of TM requires all four processes to be simulated simultaneously. The presented model requires the calibration of ten parameters divided in four submodels during two hydrological conditions (low and high flow). All parameters could be explained by the physical properties of the case study, suggesting that the model could be applied to other case studies. The strategy of using different datasets under different hydrological conditions highlights: (a) the importance of transient storage in the study case, (b) a detailed description of the erosion and sedimentation processes of SPM, and (c) the importance of TM eroded from the sediment as a secondary delayed source for surface water.
\end{abstract}

\section{Introduction}

Trace metals (TM) are a class of pollutant that can put ecosystems under pressure. This is particularly the case in fluvial systems since these are the major transport paths from land to sea.

\footnotetext{
* Corresponding author. Tel.: +33 0664506175.

E-mail addresses: cyril.garneau@ensat.fr, cyrilgarneau@gmail.com (C. Garneau).
}

The transfer of TM is primarily affected by the river hydrology (Shafer et al., 1997; Lanceleur et al., 2011). Other processes can also significantly affect the path and fate of TM, such as physicochemistry (Christensen and Christensen, 2000; Tipping et al., 2003; Cao et al., 2006), organic matter (Tipping, 1994; Ladouche et al., 2001; Garnier et al., 2006) and erosion-sedimentation (Ji et al., 2002; Lindenschmidt et al., 2005). However, few studies focus on the role of hydromorphology in the fate of TM. Hydromorphology primarily includes the influence of erosion and sedimentation zones. It also 
includes storage zones, such as dead arms or the hyporheic zone, and complex stream geometry, such as riffle-pool sequences. For example, Bonvallet et al. (2001) demonstrated the importance of hydromorphology in the retention of phosphorus, especially in the hyporheic zone. This retention was closely linked to the river's hydrology and morphology.

In river waters, TM travel either in dissolved or particulate form based on filtration criteria (Dai and Martin, 1995; Garnier et al., 2006). Therefore, their fate is highly dependent on the fate of suspended particulate matter (SPM) which, in turn, is highly linked to hydrology and morphology through erosion and sedimentation processes.

As TM dynamics are complex, modelling trace metals in river systems requires a proper description of several processes, for each of which different approaches can be used. To simulate the river's flow, hydrodynamic models are usually based on Saint Venant equations, either in their simplified form, as used for example in the SWAT model (Neitsch et al., 2009) or in their complete form, as used for example by WASP5 (Ambrose et al., 1993), CE-QUAL2 (Brunner, 1995), HEC-RAS (Cole and Wells, 2008) or the Mohid River Network (Trancoso et al., 2009). The transport of suspended elements can then be calculated by mass balance over each river segment (the SWAT approach) or through the use of the advection and dispersion equations (the WASP5, CE-QUAL2, HEC-RAS, Mohid River Network models). However, the advection and dispersion equations are not always sufficient to describe fully the transport of a suspended element in natural rivers due to their heterogeneity (Haggerty et al., 2002; Gooseff et al., 2005; Zarnetske et al., 2007). Therefore, various transport models have been developed to quantify this heterogeneity by including transient storage, such as the one-dimensional transport with inflow and storage (OTIS) model (Bencala and Walters, 1983; Runkel and Broshears, 1991) or the variable residence time model (VART) (Deng and Jung, 2009). The erosion and sedimentation processes, controlling the fate of SPM, are also well documented and modelled. The two main approaches include "transport capacity", as defined by Bagnold (1977) and used in the SWAT model, and the Partheniades equations (Partheniades, 1965), relying on the computed shear stress on the riverbed. Finally, TM can migrate from the dissolved phase to the particulate phase and vice versa. If a modelling choice can be to neglect this dynamic, the most common description of this dependency is through the coefficient of partition $\mathrm{Kd}$, a constant ratio between the particulate and the dissolved phase (Dai and Martin, 1995; Allison and Allison, 2005). However, more complex separation models, such as the Freundlich or Langmuir isotherms, could be employed, or a fully mechanistic approach based on chemical speciation modelling, such as MINTEQA2 (Allison et al., 1991), PHREEQC (Parkhurst and Appelo, 1999) or WHAM (Tipping, 1994), could be sought. The one-dimensional transport with equilibrium chemistry (OTEQ) (Runkel, 2009) combined, for example, the OTIS and the MINTEQA2 models.

In practice, most TM modelling attempts have been performed in a single hydrological condition, either during flood conditions ( $\mathrm{Ji}$ et al., 2002) or steady state conditions (Runkel and Broshears, 1991; Lindenschmidt et al., 2006). Furthermore, most studies involving transient storage models have been performed in small rivers or creeks (Runkel et al., 1999; Gooseff et al., 2003; Caruso, 2004). Therefore, the influence of contrasted hydrology on TM modelling in a large river is still rudimentary.

The objective of the present study was to assess the modelling of trace metals in a large river based on a mechanistic, dynamic and discretised model by integrating hydromorphology and a transient storage zone, SPM dynamics and a constant coefficient of separation between the dissolved and particulate phase of the $\mathrm{TM}$, known as the Kd coefficient. The most influential parameters and processes involved at the reach scale were then identified. The middle course of the Garonne River (southwest France) was used as the case study.

\section{Materials and methods}

\subsection{Model development}

The trace metal model includes four different submodels. They are included in order of dependency. Therefore, each submodel depends on those described before and is assumed independent of those that follow. The order of these submodels is:

1. Hydrodynamic submodel.

2. Solute transport submodel.

3. Erosion-sedimentation submodel.

4. Sorption-desorption submodel.

For example, the solute transport needs inputs from the hydrodynamic model, but is independent of the erosion-sedimentation and TM transport models. The processes are schematised in Fig. 1. Therefore, the four submodels are solved sequentially at each 10 s time step.

The hydrodynamic and solute transport submodels are described by a one-dimensional (1-D) representation. The river is discretised into subsections of variable lengths and the resolution of these two submodels requires the resolution of the whole river submodel. The erosion-sedimentation and sorptiondesorption submodels, in turn, are not discretised. These submodels are applied to each river subsection without any interaction with the rest of the river.

\subsubsection{Hydrodynamic submodel}

The hydrodynamic model integrates 1-D Saint Venant equations, also known as the dynamic wave by Chow et al. (1988), to propagate the water in the river Eqs. (1) and (2):

$\frac{\partial Q}{\partial x}+\frac{\partial A}{\partial t}=0$

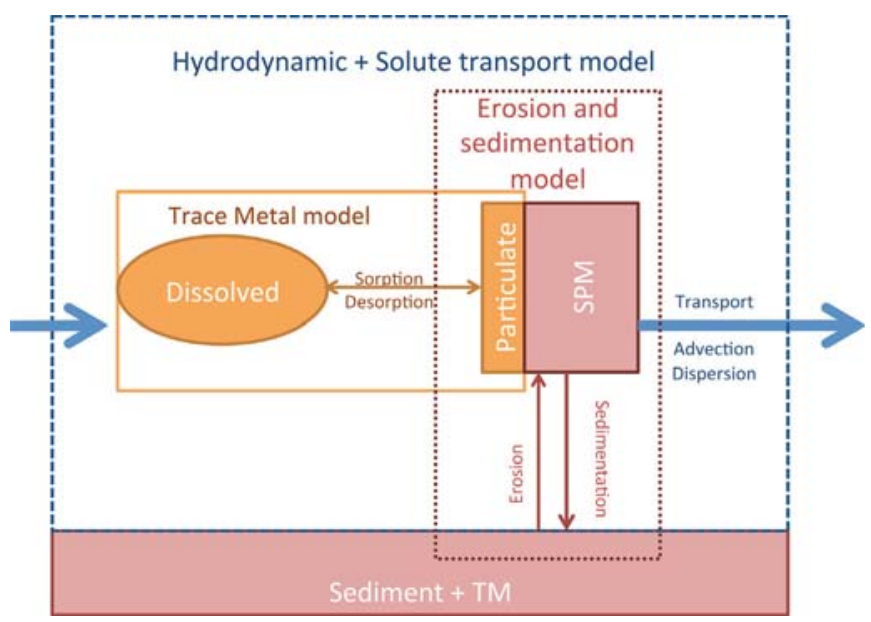

Fig. 1. Schematic representation of the TM modelling approach over a finite volume element of the river. The hydrodynamics and solute transport through advectiondispersion are represented in blue. They compute the longitudinal transport of both water and suspended elements (dissolved and particulate, blue arrows). The erosion-sedimentation model corresponds to the vertical transport of suspended particulate matter (SPM) between the immobile bottom of the river and the mobile water body. Finally, the trace metal model assesses the form taken by the trace metal (TM), either dissolved or particulate, through a sorption-desorption model based on a fixed separation coefficient $\mathrm{Kd}$. (For interpretation of the references to colour in this figure legend, the reader is referred to the web version of this article.) 
$\left.\frac{\delta Q}{\delta t}+\frac{\delta}{\delta x}\left(\frac{Q^{2}}{A}\right)+g A \frac{\delta y}{\delta x}-S_{0}+\frac{Q^{2}}{K_{\mathrm{s}}^{2} A^{2} R_{\mathrm{h}}^{4 / 3}}\right)=0$

where $Q$ is the flow $\left(\mathrm{m}^{3} \mathrm{~s}^{-1}\right), x$ the longitudinal distance along the channel ( $\mathrm{m}), A$ the cross-section of the river $\left(\mathrm{m}^{2}\right), t$ the time (s), $g$ the gravitational acceleration $\left(\mathrm{m} \mathrm{s}^{-2}\right), y$ the water level of the river $(\mathrm{m})$, So the riverbed slope $\left(\mathrm{m} \mathrm{m}^{-1}\right), K_{\mathrm{s}}$ the Strickler coefficient $\left(\mathrm{m}^{1 /}\right.$ ${ }^{3} \mathrm{~s}^{-1}$, inverse of the Manning coefficient) and $R_{\mathrm{h}}$ the hydraulic radius $(\mathrm{m})$.

The Saint Venant equations are implemented in FORTRAN and solved using an implicit finite elements method. This implementation was first used in Sauvage et al. (2003). It takes as inputs the river slope, the bathymetry and boundary conditions (upstream and downstream) and provides as outputs the water height and velocity, the wet perimeter, the cross-section area of the river and some key hydraulic variables such as hydraulic radius and shear stress at the bottom of the river. It allows both steady state computations and dynamic simulations with variable inflow. The only free parameter is the Strickler coefficient.

\subsubsection{Dissolved transport submodel}

The transport model chosen is the one-dimensional transport with inflow and storage (OTIS) model developed by Bencala and Walters (1983). OTIS includes standard advection and dispersion equations and adds a transient storage reservoir that allows the heterogeneity of the river to be taken into account. The concentration of a given species in the river varies according to Eq. (3) and the concentration in the transient storage zone varies according to Eq. (4):

$\frac{\delta C}{\delta t}=-\frac{Q \delta C}{A \delta x}+\frac{1 \delta}{A \delta x}\left(A D \frac{\delta C}{\delta x}\right)+\alpha\left(C_{\mathrm{s}}-C\right)$

$\frac{\mathrm{d} C_{\mathrm{s}}}{\mathrm{d} t}=\alpha \frac{A}{A_{\mathrm{s}}}\left(C-C_{\mathrm{s}}\right)$

The additional variables are $C$ the concentration of the transported species in the river $\left(\mathrm{g} \mathrm{m}^{-3}\right), D$ the dispersion coefficient $\left(\mathrm{m}^{2} \mathrm{~s}^{-1}\right)$ and $C_{\mathrm{s}}$ the concentration of the transported species in the transient storage zone $\left(\mathrm{g} \mathrm{m}^{-3}\right)$. The OTIS model has two free parameters: the cross-section of the transient storage zone $A_{\mathrm{s}}\left(\mathrm{m}^{2}\right)$ and the rate of exchange between the river and the transient storage zone $\alpha$ (dimensionless). The flow $Q$ and river cross-section $A$ are provided by the hydrodynamic model. The dispersion coefficient can be calibrated, but can also be hydrodynamic conditions by the Eqs. (5) and (6):

$D=d R_{\mathrm{h}} u^{*}$

$u^{*}=\frac{U \sqrt{g}}{K_{\mathrm{s}} \times R_{\mathrm{h}}^{1 / 6}}$

where $d$ is a calibration parameter (unitless), $u^{*}$ is the shear velocity $\left(\mathrm{m} \mathrm{s}^{-1}\right)$ and $U$ is the water velocity $\left(\mathrm{m} \mathrm{s}^{-1}\right)$ computed by the hydrodynamic model.

\subsubsection{Erosion and sedimentation submodel}

Most erosion models use the equations of Partheniades (1965) to simulate the erosion and sedimentation of suspended sediments. Theses equations take advantage of the shear stress, a physically meaningful variable, at the bottom of the river to compute erosion or sedimentation. The sedimentation or erosion flux is computed using Eq. (7), based on the equations of Rossi (2004):

$$
\frac{\mathrm{d} M}{\mathrm{~d} t}=\left\{\begin{aligned}
C_{\mathrm{SPM}} \times W_{\mathrm{c}} \times\left(1-\frac{\tau}{\tau_{\text {sed }}}\right) & \text { if } \tau<\tau_{\text {sed }} \\
e \times\left(\frac{\tau}{\tau_{\text {ero }}}-1\right) & \text { if } \tau>\tau_{\text {ero }}
\end{aligned}\right.
$$

where $\mathrm{d} M / \mathrm{d} t$ is the eroded or deposited flux of SPM $\left(\mathrm{g} \mathrm{m}^{-2} \mathrm{~s}^{-1}\right)$, $C_{\mathrm{SPM}}$ the concentration of SPM $\left(\mathrm{g} \mathrm{m}^{-3}\right), W_{\mathrm{c}}$ the sedimentation velocity $\left(\mathrm{m} \mathrm{s}^{-1}\right), \tau$ the shear stress at the river bed interface (Pa), $\tau_{\text {sed }}$ the critical shear stress for sedimentation (Pa), $\tau_{\text {ero }}$ the critical shear stress for erosion (Pa) and $e$ the erosion constant $\left(\mathrm{g} \mathrm{m}^{-2} \mathrm{~s}^{-1}\right)$.

Shear stress is computed with respect to the hydrodynamic conditions using Eq. (8):

$\tau=\rho \times g \times \frac{U^{2}}{K_{\mathrm{S}}^{2} R_{\mathrm{h}}^{1 / \mathrm{a}}}$

where $\rho$ is the density of water $\left(\mathrm{kg} \mathrm{m}^{-3}\right)$.

The inputs to the erosion model are the shear stress at the bottom of the river $(\tau)$ and the concentration of SPM transported by the transport model. The model then needs four parameters to be calibrated: $W_{\mathrm{c}}, e, \tau_{\text {sed }}$ and $\tau_{\text {ero. }}$. Particulate TM is subject to the same equations and parameters as SPM. The only difference is the erosion constant, which is calculated using Eq. (9):

$e_{T M}=C_{T M} \times e$

where $e_{\mathrm{TM}}$ is the erosion constant of the $\mathrm{TM}\left(\mathrm{g} \mathrm{m}^{-2} \mathrm{~s}^{-1}\right), C_{\mathrm{TM}}$ is the concentration of TM in the SPM (gram of TM per gram of SPM) which needs to be measured or calibrated and $e$ is the same erosion constant of the SPM as in Eq. (7).

\subsubsection{Sorption and desorption submodel}

Trace metal concentrations are present in the water in two phases: particulate and dissolved. Both phases travel in the river continuum with the transport model. However, particulate elements can sediment in the pools with the help of the erosion-sedimentation model. In addition, freshly eroded SPM can contribute to the TM mass balance.

The sorption model chosen considers a constant $\mathrm{Kd}$, the partition coefficient between the dissolved and particulate phase based on SPM concentration. Since the erosion-sedimentation process represents a source and a sink of SPM, and thus of particulate TM, the equilibrium between the two phases of TM can be disrupted. The sorption model is then applied to re-equilibrate the two phases. The chosen form is Eq. (10), based on Allison and Allison (2005):

$\mathrm{Kd}=\frac{\mathrm{TM}_{\text {part }}(\mu \gamma / \mathrm{kg})}{\mathrm{TM}_{\text {diss }}(\mu \gamma / \mathrm{l})}$

where $\mathrm{Kd}$ is the partition coefficient $\left(\mathrm{kg}^{-1}\right), \mathrm{TM}_{\text {part }}$ the particulate concentration of TM in SPM $\left(\mu \mathrm{g} \mathrm{kg}^{-1}\right)$ and $\mathrm{TM}_{\text {diss }}$ the dissolved concentration of TM $\left(\mu \mathrm{gl}^{-1}\right)$.

\subsection{Study site}

The Garonne River (southwest France) is the third largest river in France and is eighth order at its mouth. It exhibits a nivo-pluvial regime with the influence of winter snow precipitation in the Pyrenean mountains at its inlet (Pardé, 1935). Fig. 2a shows the extent of the Garonne River from the southern part of France to its outlet in the west. The study site is the middle course of the Garonne along an $80 \mathrm{~km}$ reach starting at the outlet of the city of Toulouse (800,000 inhabitants) (Fig. 2b). The downstream limit of the study site is before the influence of the Malause reservoir. The hydrology of the Garonne River is well known at the Verdun gauging station, in the middle part of the study site (G5 on Fig. 2b). At this point, the Garonne has a watershed of $13,730 \mathrm{~km}^{2}$ and an annual average flow of $193 \mathrm{~m}^{3} \mathrm{~s}^{-1}$. The monthly average flow 


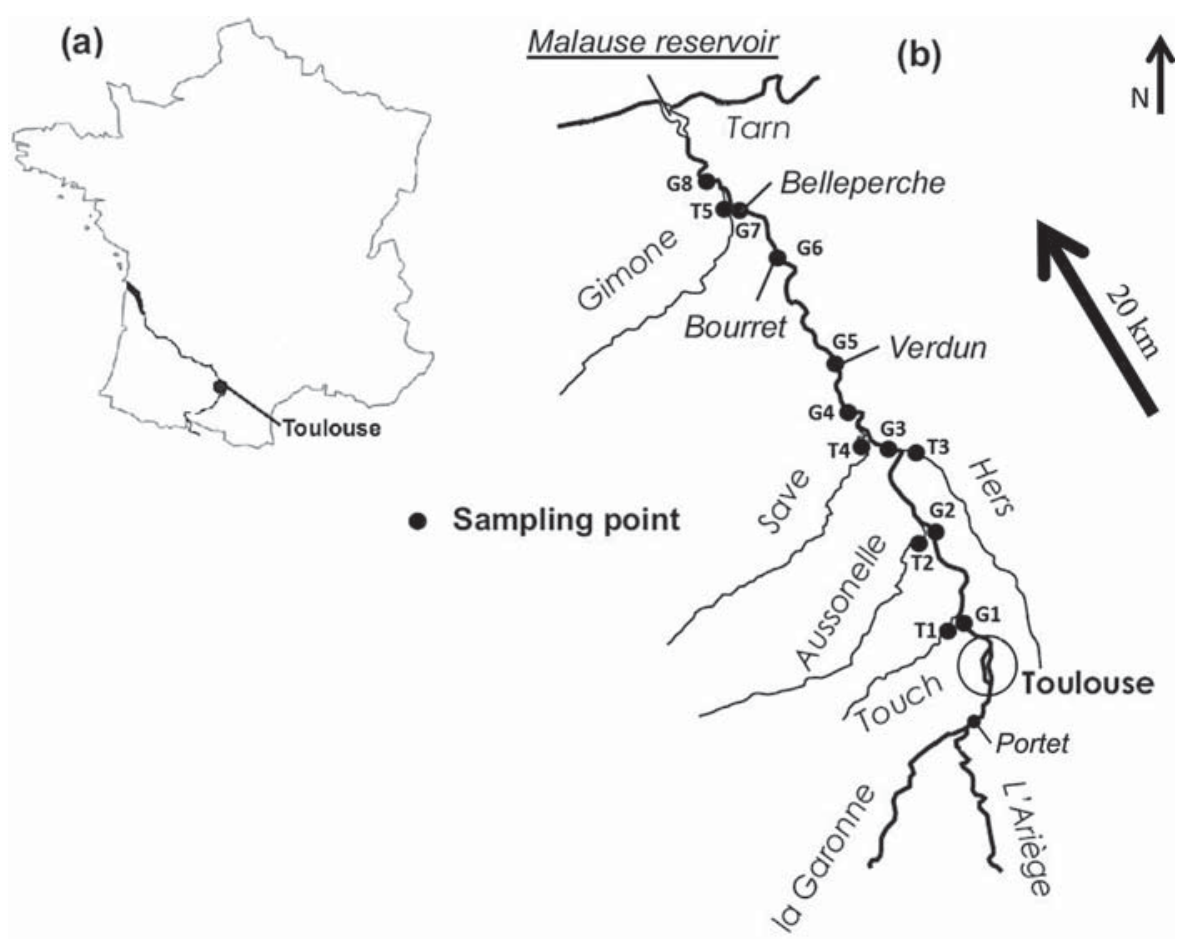

Fig. 2. The Garonne River study site in southern France. The SPM and TM sampling sites on the main river course are indicated by "Gx" symbols and on the sampled tributaries by "Tx" symbols.

ranges from $75 \mathrm{~m}^{3} \mathrm{~s}^{-1}$ in August to $341 \mathrm{~m}^{3} \mathrm{~s}^{-1}$ in May. The 10 day low-water average with a return period of two years is $42 \mathrm{~m}^{3} \mathrm{~s}^{-1}$ while the daily average flow of the two-year return flood reaches $1400 \mathrm{~m}^{3} \mathrm{~s}^{-1}$ (Banque Hydro, http://www.hydro.eaufrance.fr/).

The Garonne River exhibits successions of riffles and pools (Steiger and Gurnell, 2003). This morphological characteristic means that successive erosion and sedimentation zones can be observed in the $80 \mathrm{~km}$ reach of the study. In addition, an important gravel bed can be observed. Gravel beds are known to generate important interactions between the river and the groundwater for phosphorus and nitrate (Bonvallet Garay et al., 2001; Teissier et al., 2008 Teissier et al., 2008). The Garonne watershed also exhibits a limited contamination in TM. Bur et al. (2009) reported enrichment factors for $\mathrm{Pb}$ up to 10.1 with respect to the regional geochemical background. Arsenic (As) levels are close to the geochemical background (Aubert et al., 2014; Drever, 1997), although the As geochemical background of the Garonne watershed in higher than the world average (Masson et al., 2007). Therefore, the Garonne River is subject to low-to-moderate metallic pollution along the study site.

\subsection{Available data for model construction and calibration procedure}

Different datasets were used to calibrate the submodel parameters sequentially. The automatic calibration was performed with the simplex method from Nelder and Mead (1965), implemented in the Octave free programming environment (http://www.gnu.org/software/octave/). The maximization of the Nash-Sutcliffe efficiency criterion (see Section 2.4) was used as the optimisation objective.

\subsubsection{Hydrodynamic data}

The morphology of the river is assessed by more than 100 cross-sectional profiles along the reach gathered by various public institutions such as France's "Direction Départementale de l'Équipement" (DDE-Departmental Office of Infrastructure) or
France's "Direction Régionale de l'Environnement" (DIREN Regional Department for the Environment). These profiles allowed a detailed description of the riverbed slope and cross-section to be included in the model and were first used in Sauvage et al. (2003).

The Strickler parameter was calibrated and validated with hourly measurements of water levels and discharges from two gauging stations from $07 / 02 / 2002$ to $08 / 04 / 2002$. This period showed flows ranging from low to medium, thus allowing simulations over a significant range of water velocity. The water levels were measured and converted into discharges by the MidiPyrenees "Direction Régionale de l'Environnement, de l'Aménagement et du Logement" (DREAL - Regional Directorate for Environment, Development and Housing). The first gauging station is situated at Portet, upstream of Toulouse (see Fig. 2), while the second is at Verdun (point G5 on Fig. 2), $49.5 \mathrm{~km}$ downstream in the middle part of the studied sector.

\subsubsection{Dissolved transport model - Tracer tests}

Two rhodamine B tracer test campaigns were performed on the Garonne River in 2007 and 2008 by private companies E.A.T.C. and SETUDE, 2008. The campaigns aimed to assess the dispersion of a dissolved pollutant in the Garonne under various hydrological conditions. Two hydrological conditions were considered, namely low water $\left(61 \mathrm{~m}^{3} \mathrm{~s}^{-1}\right)$ and high water $\left(447 \mathrm{~m}^{3} \mathrm{~s}^{-1}\right)$. As the studied sector was too long for a single injection, the river was separated into three sections of $40 \mathrm{~km}, 20 \mathrm{~km}$ and $10 \mathrm{~km}$, with the first injection performed upstream of Toulouse, the second at point G4 and the third half-way between points G5 and G6 (Fig. 2). The samples were taken by an automated sampler and kept in darkness to prevent photo-degradation. The rhodamine $\mathrm{B}$ analyses were performed using a spectrofluorimeter.

When using the 1-D OTIS model, it is important that the injected tracer is fully mixed with the river. The tracer was considered fully mixed in the river when the sampling from the middle of the river showed a similar behavior to the samples taken from the two river banks. The first sampling point meeting this 
criterion was chosen as the injection point for the simulation of the tracer test. Two injections were used to calibrate the model. The first was performed on 19 September 2007, during a low-water flow period of $61 \mathrm{~m}^{3} \mathrm{~s}^{-1}$. The injection was performed $5 \mathrm{~km}$ downstream of point $\mathrm{G} 1$ and the observations were made at point G4, for a total distance of $28.1 \mathrm{~km}$. The second injection was performed on 1 April 2008, during a flood event with a discharge of $447 \mathrm{~m}^{3} \mathrm{~s}^{-1}$. The injection was made at point G2 and the observations were made at point $\mathrm{G} 3$, for a total distance of $12.7 \mathrm{~km}$. These observations allowed a calibration of the three parameters of the OTIS model, namely the storage cross-section area AS, the exchange coefficient $\alpha$ and the dispersion parameter $d$. This last parameter $d$ was set to 100 based on previous results (Sauvage et al., 2003). The two remaining parameters were estimated by automatic calibration for both low water and flood events.

\subsubsection{Suspended particulate matter and trace metal data}

SPM and trace metals have been measured in the waters of the Garonne River and its tributaries (Sánchez-Pérez et al., 2006) in the various sampling stations on the Garonne River (Gx) and its tributaries (Tx) indicated in Fig. 2, according to the sampling method of Teissier et al. (2008). The sampling method consisted of sampling the same water body as it progressed to the outlet of the river. Therefore, when a flood event occurred, the various sampling points were sampled by following the flood wave to the outlet of the river. The first campaign was performed on 17 and 18 May 2005 during a flood event (flow of $800 \mathrm{~m}^{3} \mathrm{~s}^{-1}$ ). The second occurred on 10 November 2005 after three weeks of low water (flow of $80 \mathrm{~m}^{3} \mathrm{~s}^{-1}$ ) (Fig. 3).

SPM from upstream of the river and from the tributaries measured during the two sampling campaigns were used as inputs for the erosion-sedimentation submodel. Observations along the longitudinal profile were used for the calibration of the four free parameters: $\tau_{\text {ero }}, \tau_{\text {sed }}, W_{\mathrm{c}}$ and $e$.

Within the scope of this work, two trace metals - arsenic (As) and lead $(\mathrm{Pb})$ - were chosen as they are known to have a different chemical affinity to suspended matter in the Garonne River and thus different sorption/desorption behaviors (Allison and Allison, 2005). Arsenic mainly exhibits a dissolved fraction under most hydrological conditions with $\log (\mathrm{Kd})$ between 2.0 and 6.0 and a median of 4.0 according to Allison and Allison (2005). In contrast, lead is usually encountered in particulate form. $\log (\mathrm{Kd})$ found in literature ranges from 3.4 to 6.5 with a median value of 5.6 (Allison and Allison, 2005). This data is consistent with data observed at the Portet station (Aubert et al., 2014). The samples were treated according to the procedures described by in N'guessan et al. (2009), Roussiez et al. (2013) and Aubert et al. (2014) and summarized below. Water samples were filtrated through $0.22 \mu \mathrm{m}$ Millipore GSWP-type membranes for trace metal analysis. SPM was removed from the filter using ultrasound with a recovery rate of between 70 and $100 \%$ to avoid filter contamination for some

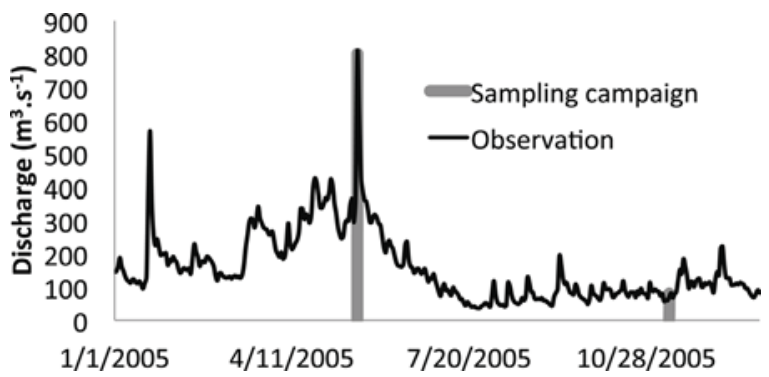

Fig. 3. Discharge variations of the Garonne River at station G5 during 2005. SPM and TM sampling campaigns are indicated by the grey line. elements that can occur if there is complete dissolution. Particles were then transferred into Teflon bombs and evaporated until completely dry. SPM dissolution was performed in a hot mixture of bi-distilled $\mathrm{HNO}_{3}$ and $\mathrm{HF}$ and ultrapure $\mathrm{H}_{2} \mathrm{O}_{2}$ in a clean room using a well-calibrated procedure. Trace elements (As and $\mathrm{Pb}$ ) in the dissolved fraction of the water and SPM were measured using a PerkinElmer Elan 6000 ICP-MS. The detection limit was below $0.01 \mu \mathrm{g} / \mathrm{l}$ and the error of measurement was generally less than $5 \%$ for most of the elements. Standard materials were used during the procedure allowing effective control of the dissolution procedure and the analytical process.

Two model parameters are specifically related to the TM simulations: $\mathrm{Kd}$ and the concentration of TM in the SPM $C_{\mathrm{TM}}$. Within the scope of the study, the Kd coefficient was fixed to the average Kd observed during the sampling campaigns. This choice allowed one free parameter to be removed from the model's autocalibration.

\subsection{Efficiency criteria}

Two efficiency criteria were used to assess the performance of the calibrations. The first was the Nash-Sutcliffe criterion (NS, Eq. (11)), which compared the square error between the observation and the simulation to the square error between the observation and the mean of the observations. An NS of 1 is indicative of a perfect model, a value of 0 means that the model is a predictor that is as good as the average of the observations, and a value below 0 means that the average of the observations is a better predictor than the model.

$\mathrm{NS}=1-\frac{\sum\left(Q_{\mathrm{obs}}-Q_{\text {sim }}\right)^{2}}{\sum\left(Q_{\mathrm{obs}}-Q_{\mathrm{obs}}\right)^{2}}$

Eq. (11) was used to assess the performance of the hydrodynamic module, the transport module and the erosion module. However, the trace metal module generates three components (dissolved phase, particulate phase and total concentration) and a single criterion was needed to perform the calibration. Since the average of the three components has no physical meaning, the NashSutcliffe was modified (Eq. (12)). This modification allowed the components of different magnitudes to be compared:

$$
\begin{aligned}
& N S_{\text {mod }}=1 \\
& -\frac{\sum\left(C_{\text {disøbs- }-} C_{\text {dissim }}\right)^{2}+\Sigma\left(C_{\text {parbbs_- }} C_{\text {partim }}\right)^{2}+\Sigma\left(C_{\text {tobbs_- }} C_{\text {partim }}\right)^{2}}{\Sigma\left(C_{\text {dissbs }-} C_{\text {dis sobs }}\right)^{2}+\Sigma\left(C_{\text {parbbs }-} C_{\text {parbbs }}\right)^{2}+\Sigma\left(C_{\text {tobbs }-} C_{\text {tobbs }}\right)^{2}}
\end{aligned}
$$

The second efficiency used was the coefficient of correlation that quantifies the correlation between two variables (Eq. (13)). For trace metals, the average of the correlation of the dissolved phase, the particulate phase and the total concentration was provided:

$r=\frac{\sigma_{Q_{\text {obs }} Q_{\text {obs }}}}{\sigma_{Q_{\text {obs }}} \times \sigma_{Q_{\text {sim }}}}$

\section{Results and discussion}

\subsection{Hydrodynamic model}

River discharge was calibrated with a mean Strickler coefficient of 48 (Fig. 4). The NS of the calibration period (12 days of hourly observations) is 0.82 while the $r$ is 0.98 , which means that the model is capable of representing the flow well. For the 10-day validation period, the NS reaches 0.96 and the $r$ is 0.97 .

The hydrodynamic model demonstrated a good representation of the observations. However, over the $49.5 \mathrm{~km}$ between the two 

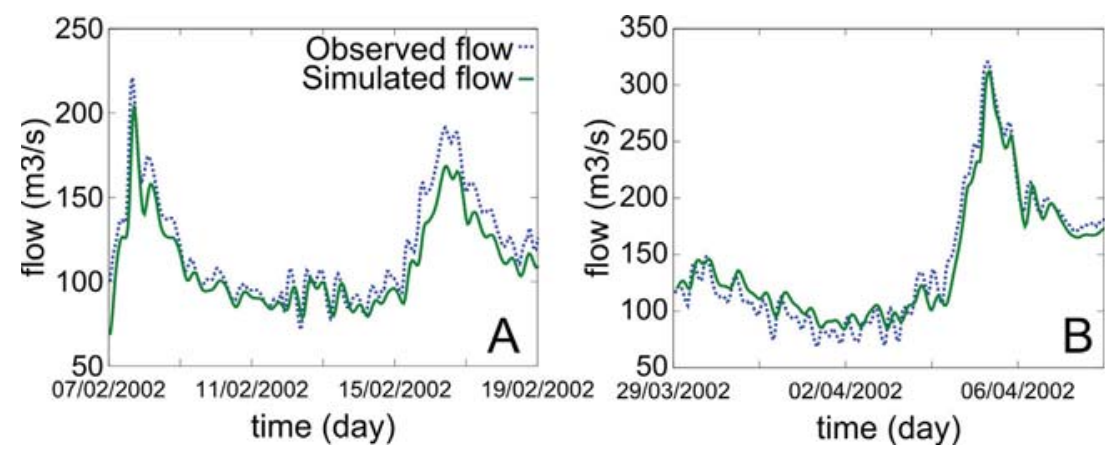

Fig. 4. Calibration (4A) and validation (4B) of the hydrodynamic model. The inflow was performed upstream of Toulouse and the simulation is compared to the discharge observations at the Verdun gauging station (G5 on Fig. 2). There was a distance of $49.5 \mathrm{~km}$ between upstream and downstream. Calibration was performed with hourly data from $07 / 02 / 2002$ to $19 / 02 / 2002$ and validation from $29 / 03 / 2002$ to $08 / 04 / 2002$. It can be seen that the model is capable of predicting the temporal variability of the flow.

gauging stations, the Strickler parameter only influenced the velocity of the water. The mismatch between the observed flow and simulated flow includes the mass balance error (unknown inputs from smaller tributaries or uptake by irrigation) and measures uncertainty.

A Strickler parameter of 48 is similar to a Manning coefficient of 0.021. According to literature (Chow et al., 1988), a Manning coefficient of this level is characteristic of rivers that have a gravel bed and concrete or mortared stone sides. This description fits the Garonne River well as it exhibits a gravel bed with frequent ripraps along the studied sector (Steiger et al., 1998). The one-dimensional model provided a good relationship between the automatic calibration and physical signification of the Manning parameter thanks to the large number of cross-section profiles providing a very good bathymetry of the river.

\subsection{Transport model}

The tracer experiment allowed the OTIS model to be calibrated and the influence of the morphology of the river on the transport of dissolved element to be quantified. Furthermore, calibrating the hydraulics first allowed the velocity of the flow to be distinguished from the velocity of the dissolved elements in the water. The morphology of the river could therefore be highlighted.

The transport model was calibrated on two distinct tracer campaigns: low and high water $\left(61 \mathrm{~m}^{3} \mathrm{~s}^{-1}\right.$ and $447 \mathrm{~m}^{3} \mathrm{~s}^{-1}$, Fig. 5). The optimal parameters are shown in Table 1. The dispersion parameter $d$ of Eq. (5) was fixed to 100 based on the results of Sauvage et al. (2003) in the same sector.
The optimal parameter sets were different for low water and high water, although they were of the same magnitude in both hydrological conditions. The transient storage cross-section was greater during high water, which was to be expected as the river cross-section is larger during high water than during low water. The exchange rate, however, reacted inversely by having a higher value during low water. The dispersion range observed was of the same order of magnitude for both events. Using two different parameter sets allowed NS and $r$ criterion very close to one to be obtained, which indicated a very good fit. The parameters compared favorably with literature (Bencala and Walters, 1983; Ambrose et al., 1993; Runkel et al., 1999). Furthermore, the application of OTIS on the Garonne River case study was strengthened by the morphology of the river, which shows a succession of riffles and pools (Pardé, 1935; Sauvage et al., 2003), since Runkel et al. (1999) suggested that the pools can have a significant storage capacity of dissolved elements capable of slowing their transport. Peyrard et al. (2008) also showed the activity of the hyporheic zone in the studied sector, thus increasing the potential volume of the transient storage zone.

Accurate simulation of the transport of the dissolved element required consideration of the river's transient storage zones. In fact, by ignoring transient storage, the only free parameter is $d$ and its optimal value was 4,865 during high water and 17,544 during low water. Such values lead to a dispersion coefficient D in the range of $72-1370 \mathrm{~m}^{2} \mathrm{~s}^{-1}$ during high water and $5-5,260 \mathrm{~m}^{2} \mathrm{~s}^{-1}$ during low water and gave an NS criterion of 0.63 (high water) and -1.6 (low water). These unrealistic dispersion coefficients also resulted in the simulated tracer peak concentrations occurring
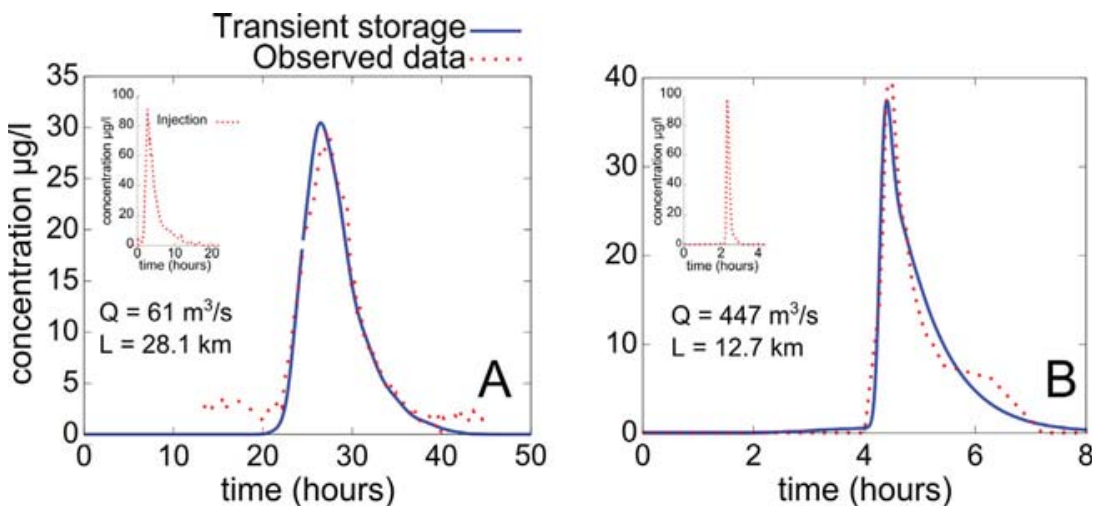

Fig. 5. Rhodamine B tracer experiment. Observations were made at sampling site G4 during low water (A) and at sampling site G3 during high water, (B) the injection profile is given for both experiments in the sub-graphics. The injection for the low-water experiment was performed $5 \mathrm{~km}$ downstream of sampling site $\mathrm{G} 1$, giving a distance between injection and observation of $L=28.1 \mathrm{~km}$ and a flow of $Q=61 \mathrm{~m}^{3} \mathrm{~s}^{-1}$. The injection in the high-water experiment was performed at sampling point $\mathrm{G} 2$, for a distance between injection and observation of $L=12.7 \mathrm{~km}$ and a flow of $Q=447 \mathrm{~m}^{3} \mathrm{~s}^{-1}$. 
Table 1

Calibrated parameter values of the OTIS model for the two hydrological conditions (low and high flows) with the rhodamine tracer experiments.

\begin{tabular}{llllll}
\hline & As $\left(\mathrm{m}^{2}\right)$ & $\alpha\left(\mathrm{s}^{-1}\right)$ & $\mathrm{D}\left(\mathrm{m}^{2} . \mathrm{s}^{-1}\right)$ & $\mathrm{NS}$ & $r$ \\
\hline Low water & 56.8 & $7.01 \mathrm{E}-4$ & $0.03-30$ & 0.97 & $0.99(n=94)$ \\
High water & 77.2 & $2.20 \mathrm{E}-4$ & $1.4-28$ & 0.95 & $0.98(n=14)$ \\
\hline
\end{tabular}

15 min earlier (high water) and eight hours earlier (low water) than the observed peak concentrations.

\subsection{Erosion model}

The calibrated results and parameters of the SPM concentrations are shown in Fig. 6 and Table 2, respectively for low and high-flow conditions. The NS of the low-flow simulation was 0.04 but the correlation coefficient $r$ of $0.87(n=7, p<0.01)$ indicated that the general trend of the SPM concentration was well represented by the model. This low NS is typical of simulation results close to their average value (Criss and Winston, 2008) and has to be interpreted with the $r$ coefficient.

During the high-water flow event, the model performed much better with NS of 0.45 and $r$ of $0.96(n=7, p<0.01)$. The comparison of the low-flow and high-flow parameter sets and simulation trends suggested that SPM characteristics might be different during the two hydrologically contrasting periods. It should also be noted that the concentrations of SPM were almost two orders of magnitude higher during the flood period than during the low flow (Fig. 6).

The critical shear stress of sedimentation $\left(\tau_{\text {sed }}\right)$ and the falling velocity $\left(W_{\mathrm{c}}\right)$ exhibited more than one order of magnitude of difference between the two events, being much lower during the low-water event. The parameters related to erosion (the critical shear stress of erosion $\tau_{\text {ero }}$ and the erosion constant $e$ ) were much higher during the flood event, but remained within one order of magnitude of the values calculated during the low waters (Table 2).

The most plausible explanation for the mismatch between the model and the observations is the absence of autochthonous organic matter production in the model. The Garonne River is known to have significant epilithic biofilm production during lowwater flows and many attempts have been made to simulate its fate (Boulêtreau et al., 2006; Graba et al., 2013). This biofilm produces particulate organic carbon that can contribute up to 25\% of SPM during low-water periods (Veyssy et al., 1998).

During high water, the simulation results were better, suggesting that transport and sedimentation were well represented while erosion had a limited influence. The low erosion contribution suggested that SPM did not originate from the river bed, but mostly from the watershed.
The calibrated optimal parameter set also suggested that the nature of SPM varied with hydrological conditions. The settling velocity $W_{\mathrm{c}}$ provided information on the smallest particles that could settle. In accordance with Stokes' law, it was possible to estimate the diameter of a particle with a specific settling velocity by using Eq. (14):

$$
W_{\mathrm{c}}=\frac{2\left(\rho_{\text {water }}-\rho_{\mathrm{SPM}}\right) g}{\mu} R^{2}
$$

where $\rho$ is the density of water and SPM, respectively $\left(\mathrm{kg} \mathrm{m}^{-3}\right), \mathrm{g}$ is the gravitational acceleration $\left(\mathrm{m} \mathrm{s}^{-2}\right), \mu$ is the dynamic viscosity (Pas) of water and $R$ is the average radius of the SPM (m).

By assuming an average SPM density of $2700 \mathrm{~kg} \mathrm{~m}^{-3}$, the diameter of the smallest particles that could settle was around $20 \mu \mathrm{m}$ during low-water periods and $80 \mu \mathrm{m}$ during high water. Since fine sands are usually associated with SPM having a diameter greater than $60 \mu \mathrm{m}$, the computed settling velocities suggested that fine sands could be transported in SPM during high waters, but not during low-water periods. These values were consistent with the observations of Steiger and Gurnell (2003) who studied sediments deposited after three flood events and found that particles greater than $63 \mu \mathrm{m}$ contributed up to $85 \%$ of the total deposited sediment.

The results from the different hydrological conditions also suggested that a dynamic model capable of simulating the fate of SPM under all hydrological conditions would need at least two classes of SPM. The first would include the very fine material that is likely to stay in suspension along the whole river and the second would represent the fine material capable of sedimentation.

\subsection{Trace metal model}

The longitudinal profiles of observed and simulated concentrations for $\mathrm{As}$ and $\mathrm{Pb}$ are shown in Fig. 7 and the calibrated parameters and efficiency criterion in Table 3. The parameters used for both trace metals showed little variability independent of the hydrological condition. The $N S_{\text {mod }}$ score indicated a better agreement between observations and simulation during highwater flow conditions for both TM, while the average $r$ suggested that the model could simulate the trend of the two TM.

During the low-water flow period, As was highly dissolved (Fig. 7A), as has already been observed in the Garonne River (Aubert et al., 2014). Nevertheless, during high-water flows, the much higher concentration of SPM led to a larger fraction of As in the particulate phase than in the dissolved one (Fig. 7B). The increase of concentration of total As could also be linked almost completely to the particulate fraction of As, since the dissolved fraction remained in similar concentrations during both events. Therefore, although As is quite soluble, in the presence of high SPM
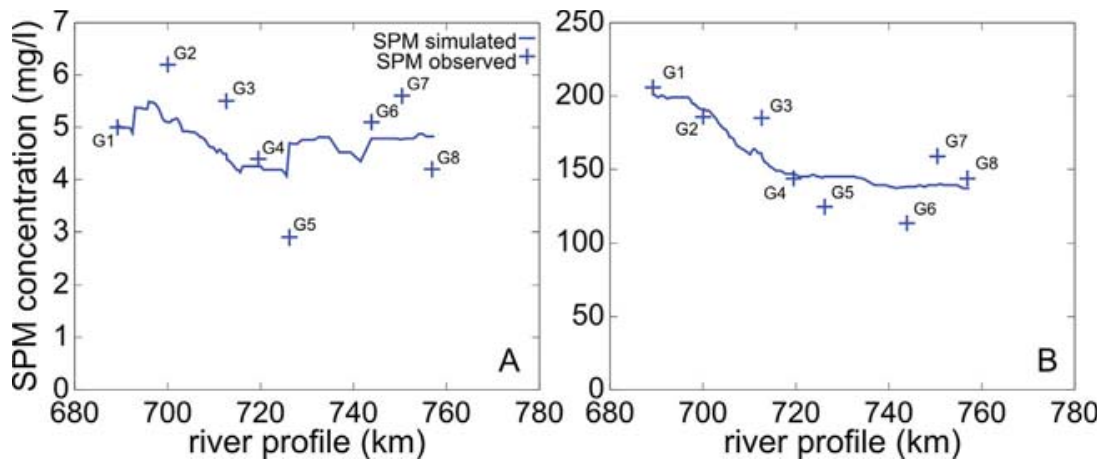

Fig. 6. SPM concentration simulated along the river continuum during low water (A, flow of $80 \mathrm{~m}^{3} \mathrm{~s}^{-1}$, continuous line) and during high water (B, flow of $800 \mathrm{~m}^{3} \mathrm{~s}^{-1}$, continuous line). Observation values at the sampling points (crosses, see Fig. 2) showed a different scale in the two hydrological conditions. 
Table 2

Calibrated parameters of the erosion and sedimentation model for the two hydrological conditions under consideration by comparing simulated and observed SPM.

\begin{tabular}{|c|c|c|c|c|c|c|}
\hline & $\tau_{\text {sed }}(\mathrm{Pa})$ & $\tau_{\mathrm{ero}}(\mathrm{Pa})$ & $\mathrm{W}_{\mathrm{c}}\left(\mathrm{m} \mathrm{s}^{-1}\right)$ & $e\left(\mathrm{~g} \mathrm{~m}^{-2} \mathrm{~s}^{-1}\right)$ & NS & $\begin{array}{l}r(n=7, \\
p<0.01)\end{array}$ \\
\hline Low water & 1.79 & 13.4 & $3.43 \mathrm{E}-4$ & $4.9 \mathrm{E}-5$ & 0.04 & 0.87 \\
\hline High water & 24.3 & 25.6 & $6.2 \mathrm{E}-3$ & $1.4 \mathrm{E}-4$ & 0.45 & 0.96 \\
\hline
\end{tabular}
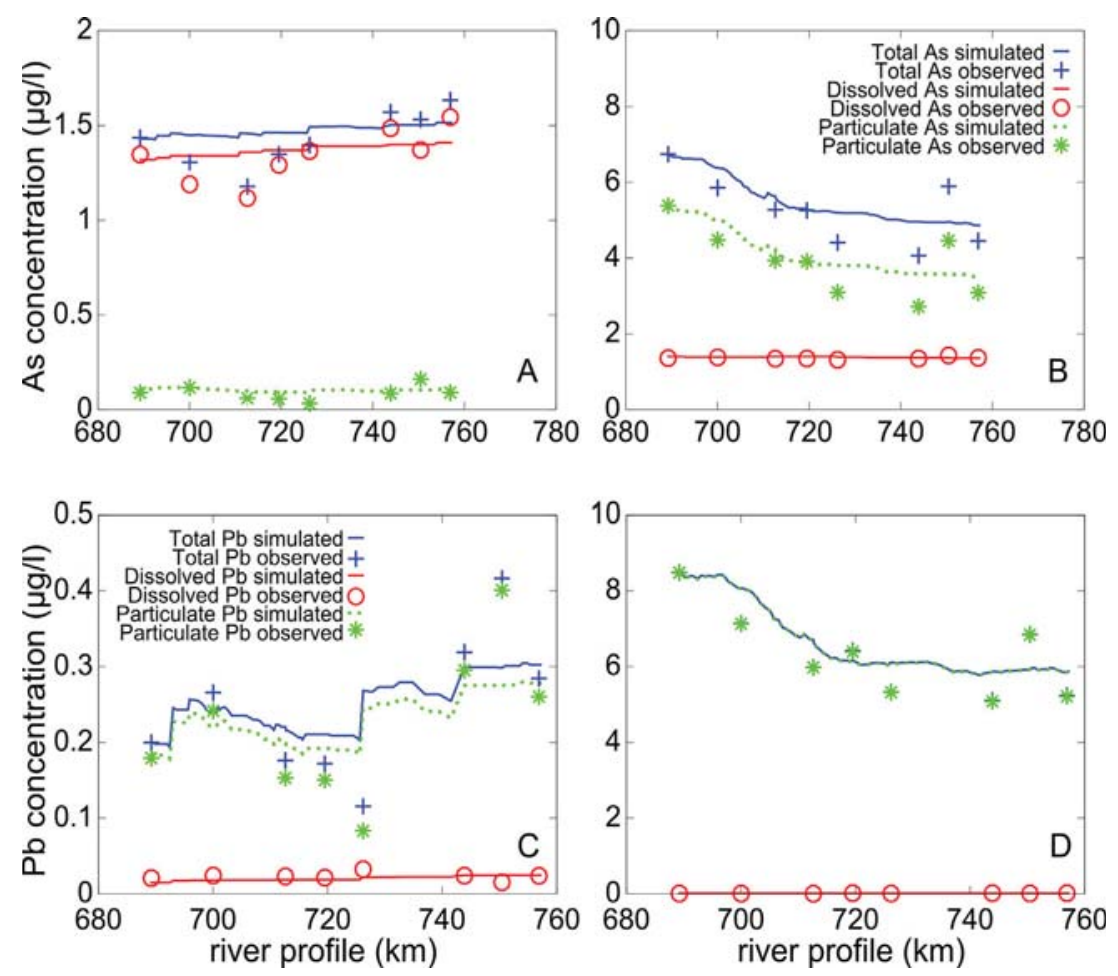

Fig. 7. Simulations of arsenic (A, B) and lead (C, D) concentrations during low-water flows (A and C, respectively, flow of $80 \mathrm{~m}^{3} \mathrm{~s}^{-1}$, continuous line) and high-water flows (B and $D$, respectively, flow of $800 \mathrm{~m}^{3} \mathrm{~s}^{-1}$, continuous line). The dissolved and particulate phases are shown with the total concentration in the water. Observation results were indicated for the different fractions and hydrological conditions using corresponding symbols. Note the different concentration scale for the two hydrological conditions.

concentrations the particulate form dominated, and erosion and sedimentation were the most important processes for explaining the fate of As.

The final three observations (between kilometers 740 and 760) of lead during the low-water simulation revealed significant concentrations (Fig. 7C). These points made the use of autocalibration problematic, thus a manual calibration was performed. Nevertheless, the simulation of $\mathrm{Pb}$ in low-water conditions followed the trend of the observations with an average $r$ of 0.44 , although $N S_{\text {mod }}$ was lower (0.34, Fig. 7C). Similar to SPM and As dynamics, during high-water conditions (Fig. 7D), total concentrations of lead were over one order of magnitude higher than for low waters. As with the arsenic simulations, the dissolved fraction of lead was predicted effectively in both low and high waters and corresponded to the observations. This highlighted the fact that the increase in total concentration was due to the particulate fraction of lead and also that the particulate fractions of both trace metals closely follow the trend of SPM concentration.

The variation in $\mathrm{Kd}$ can be explained by a variation in the physicochemistry of the water as well as by a variation in the nature of the SPM between contrasted hydrological periods. Such dependency of Kd with respect to physicochemistry and SPM composition during contrasted hydrological conditions is well known (Aubert et al., 2014; Allison et al., 1991; Tipping, 1994; Parkhurst and Appelo, 1999; Roussiez et al., 2013).

The concentration of TM in the bed sediment was fixed to obtain the best fit with the observations. If no sediment analysis was performed during the sampling campaign, SIEAG (Système d'Information sur l'Eau du Bassin Adour-Garonne - Information centre on water from the Adour-Garonne watershed, http://adourgaronne.eaufrance.fr/accesData/) collected and analysed the sediment over the 2003-2011 period, with one sample taken once a year during the low-flow period at sampling point G5 (Fig. 2). Lead concentration ranged from 5 to $23 \mu \mathrm{g} \mathrm{g}^{-1}$ of sediment with a value of $10 \mu \mathrm{gg}^{-1}$ for 2005 , the year of the sampling campaign for the present study. Arsenic concentrations ranged from 2.9 to $13 \mu \mathrm{gg}^{-1}$ with a value of $8 \mu \mathrm{gg}^{-1}$ for 2005. For both trace metals, the calibrated concentration of TM in the sediment was in the range of the concentrations observed by SIEAG. However, these concentrations are site-specific (Aubert et al., 2014; N'guessan et al., 2009). N'guessan et al. (2009) sampled the sediment on the left tributaries of the Garonne watershed from the molassic area and found average lead concentrations of $24.90 \mu \mathrm{gg}^{-1}$ and arsenic concentrations of $15.14 \mu \mathrm{gg}^{-1}$. If these values are of the same

Table 3

Calibrated values of the trace metal model parameters for the two hydrological conditions considered (low and high waters).

\begin{tabular}{lllll}
\hline & $\log (\mathrm{Kd}) \log (\mu \mathrm{g} / \mathrm{g} / \mu \mathrm{g} / \mathrm{l})$ & $\begin{array}{l}C_{\mathrm{TM}} \\
(\mu \mathrm{g} / \mathrm{g})\end{array}$ & $\mathrm{NS}_{\text {mod }}$ & $\begin{array}{l}\text { Average } \\
r(n=16)\end{array}$ \\
\hline As low water & 4.15 & 3.97 & 0.13 & 0.60 \\
As high water & 4.28 & 5.40 & 0.52 & 0.38 \\
Pb low water & 6.33 & 9.75 & 0.34 & 0.44 \\
Pb high water & 6.55 & 6.76 & 0.59 & 0.66 \\
\hline
\end{tabular}


magnitude as the calibrated parameters, the $C_{\mathrm{TM}}$ parameter has been found to be too sensitive to use these observations directly. Nevertheless, the calibrated value of TM concentration in the bed sediment proved capable of providing information about TM contamination in the sediment.

In all four cases (Fig. 7A-D), the simulation did not match the final three sampling points (G6, G7 and G8). This was the case in particular for $\mathrm{Pb}$ during low-water conditions. Considering the significant positive correlation between the trace metals and SPM, it can be hypothesised that improving the erosion model would significantly improve the TM model. This sector also showed the lowest density of river profiles, with sectors up to $2.4 \mathrm{~km}$ without profile. This low resolution of the bathymetry could lead to a poor description of the riffle-pool sequence, thus leaving out high sedimentation and erosion zones.

\section{Conclusion}

The modelling of trace metals in rivers is heavily dependent on hydrodynamics, the transport of SPM and the separation between the dissolved and particulate phases. In the present case, a dynamic, discretised model of trace metals is presented. It includes a detailed description of the hydrodynamics comprising a description of the river's morphology, transport by advection, dispersion and transient storage, erosion and sedimentation of SPM and TM, and separation of TM into dissolved and particulate phases. The model presented required the calibration of ten parameters divided into four submodels during two hydrological conditions (low and high flow). All parameters used in the current model could be explained by the physical properties of the case study, suggesting that the model can be applied to other case studies either by providing the opportunity of fixing the parameters with respect to the river properties or by calibrating parameters and providing insight into these properties. The strategy of using different datasets highlighted: (a) the importance of transient storage in the study case, (b) a detailed description of the erosion and sedimentation processes of SPM, and (c) the significance of erosion as a source of TM for surface water.

The proposed model also highlighted the influence of hydrology on the composition of SPM, and thus on the fate of TM, since the parameters were different between the two hydrological conditions. It also suggests that at least two classes of SPM should be included in the model in order to produce a model capable of tackling all hydrological conditions. Furthermore, these classes could represent different origins of SPM or its composition (i.e. organic matter from autochthonous or allochthonous origin). Finally, a detailed description of the physicochemistry of the water to assess the sorption-desorption equilibrium of TM through complex chemical models should be investigated in order to quantify its importance in the transfer of TM on larger temporal and spatial scales.

\section{Acknowledgments}

This work was funded by the French Ministry for Higher Education and Research and has been carried out as a part of "ADAPT'EAU" (ANR-11-CEPL-008), a project supported by the French National Research Agency (ANR) within the framework of "The Global Environmental Changes and Societies (GEC\&S) program". Trace metal observations were collected as part of the GIS Ecobag project, with a significant contribution made by Dominic Aubert.

\section{References}

Allison, J.D., Allison, T.D., 2005. Partition coefficients for metals in surface water, soil, and waste (No. EPA/600/R-05/074). U.S. Environmental Protection Agency. Athens, GA, US,

Allison, J.D., Brown, D.S., Novo-Gradac, K.J., 1991. MINTEQA2/PRODEFA2, A Geochemical Assessment Model for Environmental Systems: Version 3.0 User’s Manual.

Ambrose, R.B., Wool, T.A., Martin, J.L., 1993. The Water Quality Simulation Program, WASP5: Model Theory, User's Manual and Programmer's Guide. U.S. Environmental Protection Agency. Athens, GA, US.

D. Aubert, J.-L. Probst, A. Probst. Influence of hydrological conditions on trace metal behavior and dissolved/particulate partitioning in the upper Garonne and Ariège rivers (SW, France) J. Hydrol. 2014; 2014 Submitted for Publication.

Bagnold, R.A., 1977. Bed load transport by natural rivers. Water Resour. Res. 13, 303.

Bencala, K.E., Walters, R.A., 1983. Simulation of solute transport in a mountain pooland-riffle stream: a transient storage model. Water Resour. Res. 19, 718.

Bonvallet Garay, S., Sauvage, S., Vervier, P., 2001. Hydromorphological control of phosphorus in a large free-flowing gravel bed river: the Garonne River (France). Regul. Rivers Res. Manag. 17, 461-472.

Boulêtreau, S., Garabetian, F., Sauvage, S., Sánchez Pérez, J.-M., 2006. Assessing the importance of a self-generated detachment process in river biofilm models. Freshw. Biol. 51, 901-912.

Brunner, G.W., 1995. HEC-RAS River Analysis System. Hydraulic Reference Manual. Version 1.0. DTIC Document.

Bur, T., Probst, J.L., N'guessan, M., Probst, A., 2009. Distribution and origin of lead in stream sediments from small agricultural catchments draining Miocene molassic deposits (SW France). Appl. Geochem. 24, 1324-1338.

Cao, J., Xue, H., Sigg, L., 2006. Effects of pH and Ca competition on complexation of cadmium by fulvic acids and by natural organic ligands from a river and a lake. Aquat. Geochem. 12, 375-387.

Caruso, B.S., 2004. Modeling metals transport and sediment/water interactions in a mining impacted mountain stream1 JAWRA. J. Am. Water Resour. Assoc. 40, 1603-1615.

Chow, V., Maidment, D., Mays, L., 1988. Applied Hydrology, McGraw-Hill Series in Water Resources and Environmental Engineering. first ed. McGraw-Hill Science/Engineering/Math, New-York, NY, US.

Christensen, J.B., Christensen, T.H., 2000. The effect of pH on the complexation of Cd: $\mathrm{Ni}$ and $\mathrm{Zn}$ by dissolved organic carbon from leachate-polluted groundwater. Water Res. 34, 3743-3754.

Cole, T.M., Wells, S.A., 2008. CE-QUAL-W2: A Two-Dimensional, Laterally Averaged, Hydrodynamic and Water Quality Model, Version 3.6. Department of Civil and Environmental Engineering. Portland State University, Portland, OR.

Criss, R.E., Winston, W.E., 2008. Do Nash values have value? Discussion and alternate proposals. Hydrol. Process. 22, 2723-2725.

Dai, M.-H., Martin, J.-M., 1995. First data on trace metal level and behaviour in two major Arctic river-estuarine systems (Ob and Yenisey) and in the adjacent Kara Sea. Russia Earth Planet Sci. Lett. 131, 127-141.

Deng, Z.-Q., Jung, H.-S., 2009. Variable residence time-based model for solute transport in streams. Water Resour. Res. 45, 15

Drever, J.I., 1997. The Geochemistry of Natural Waters: Surface and Groundwater Environments, third ed. Prentice Hall, Upper Saddle River, N.J.

E.A.T.C. SETUDE, 2008. Etude de la propagation d'une nappe de pollution sur la Garonne Syndicat Mixte d'Etude et d'Aménagement de la Garonne

Garnier, J.-M., Ciffroy, P., Benyahya, L., 2006. Implications of short and long term (30 days) sorption on the desorption kinetic of trace metals ( $\mathrm{Cd} \mathrm{Zn}, \mathrm{Co}, \mathrm{Mn}, \mathrm{Fe}$, $\mathrm{Ag}, \mathrm{Cs}$ ) associated with river suspended matter. Sci. Total Environ. 366, 350-360.

Gooseff, M.N., Bencala, K.E., Scott, D.T., Runkel, R.L., McKnight, D.M., 2005. Sensitivity analysis of conservative and reactive stream transient storage models applied to field data from multiple-reach experiments. Adv. Water Resour. 28, 479-492.

Gooseff, M.N., Wondzell, S.M., Haggerty, R., Anderson, J., 2003. Comparing transient storage modeling and residence time distribution (RTD) analysis in geomorphically varied reaches in the Lookout Creek basin Oregon, USA. Adv. Water Resour. 26, 925-937.

Graba, M., Sauvage, S., Moulin, F.Y., Urrea, G., Sabater, S., Sánchez Pérez, J.M., 2013. Interaction between local hydrodynamics and algal community in epilithic biofilm. Water Res. 47, 2153-2163.

Haggerty, R. Wondzell, S.M., Johnson, M.A., 2002. Power-law residence time distribution in the hyporheic zone of a 2nd-order mountain stream. Geophys. Res. Lett. 29 18-1-18-1.

Ji, Z.-G., Hamrick, J.H., Pagenkopf, J., 2002. Sediment and metals modeling in shallow river. J. Environ. Eng. 128, 105-119.

Ladouche, B., Probst, A., Viville, D., Idir, S., Baqué, D., Loubet, M., Probst, J.-L., Bariac, T., 2001. Hydrograph separation using isotopic, chemical and hydrological approaches (Strengbach catchment, France). J. Hydrol. 242, 255-274.

Lanceleur, L., Schäfer, J., Bossy, C., Coynel, A., Larrose, A., Masson, M., Blanc, G., 2011. Silver fluxes to the Gironde Estuary-Eleven years (1999-2009) of monitoring at the watershed scale. Appl. Geochem. 26, 797-808.

Lindenschmidt, K., Poser, K., Rode, M., 2005. Impact of morphological parameters on water quality variables of a regulated lowland river. Water Sci. Technol. 52, 187-194. 
Lindenschmidt, K., Wodrich, R., Hesse, C., 2006. The effects of scaling and mode complexity in simulating the transport of inorganic micropollutants in a lowland river reach. Water Qual. Res. J. Can. 41, 24-36.

Masson, M., Schäfer, J., Blanc, G., Pierre, A., 2007. Seasonal variations and annual fluxes of arsenic in the Garonne Dordogne and Isle Rivers. France Sci. Total Environ. 373, 196-207.

Neitsch, S.L., Arnold, J.G., Kiniry, J.R., Williams, J.R., 2009. Soil and Water Assessment Tool - Theoretical Documentation. Texas A\&M University, USA. Agricultural Research Service and Blackland Research Centre, Texas, USA.

Nelder, J.A., Mead, R., 1965. A simplex method for function minimization. Comput. J. 7, 308-313.

N'guessan, Y.M., Probst, J.L., Bur, T., Probst, A., 2009. Trace elements in stream bed sediments from agricultural catchments (Gascogne region, S-W France): Where do they come from? Sci. Total Environ. 407, 2939-2952.

Pardé, M., 1935. Le régime de la Garonne. Rev. Géographie Pyrén Sud-Ouest 6,105-262.

Parkhurst, D.L., Appelo, C.A.J., 1999. User's guide to PHREEQC (Version 2) - A Computer Program for Speciation, Batch-Reaction, One-Dimensional Transport, and Inverse Geochemical Calculations (No. Water-Resources Investigations Report 99-4259). Denver Co..

Partheniades, E., 1965. Erosion and deposition of cohesive soils. J. Hydraul. Eng. Div. ACSE 91, 105-139.

Peyrard, D., Sauvage, S., Vervier, P., Sánchez Pérez, J.M., Quintard, M., 2008. A coupled vertically integrated model to describe lateral exchanges between surface and subsurface in large alluvial floodplains with a fully penetrating river. Hydrol. Process. 22, 4257-4273.

Rossi, L., 2004. Modélisation des matières en suspension (MES) : dans les rejets urbains en temps de pluie. GWA 84, 753-761.

Roussiez, V., Probst, A., Probst, J.-L., 2013. Significance of floods in metal dynamics and export in a small agricultural catchment. J. Hydrol. 499, 71-81.

Runkel, R.L., 2009. One-dimensional transport with equilibrium chemistry (OTEQ) - A reactive transport model for streams and rivers, in: U.S. Geological Survey Techniques and Methods Book 6, Chapter B6. p. 101 p.

Runkel, R.L., Bencala, K.E., Kimball, B.A., 1999. Modeling solute transport and geochemistry in streams and rivers using OTIS and OTEQ. Presented at the U.S. Geological Survey Toxic Substances Hydrology Program: Proceedings of The Technical Meeting, D. W. Morganwalp and H. T. Buxton, Charleston SC, pp.120-127.

Runkel, R.L. Broshears, R.E. 1991. One-dimensional transport with inflow and storage (OTIS): a solute transport model for small streams. Cent. Adv. Decis. Support Water Environ. Syst.
Sánchez-Pérez, J.-M., Probst, A. Gerino, M., Sauvage, S., Aubert, D., Devault, D. Tackx, M., Boulêtreau, S., Dalger, D., Delmas, F., Dubernet, J.F., Durbe, G., Henry, M., Julien, F., Lim P., Merlina, G., Mamoudou, M., Pinelli, E., Probst, J.-L., Vervier P., 2006. Fluvial transport and transformation of heavy metals, pesticides and biogenic elements in the Garonne river continuum system. Presented at the Man and River System II, Interactions among Rivers, their Watershed and the Sociosystem, Paris, France, pp. 49-51.

Sauvage, S., Teissier, S., Vervier, P., Améziane, T., Garabétian, F., Delmas, F., Caussade B. 2003. A numerical tool to integrate biophysical diversity of a large regulated river: hydrobiogeochemical bases. The case of the Garonne River (France). River Res. Appl. 19, 181-198.

Shafer, M.M., Overdier, J.T., Hurley, J.P., Armstrong, D., Webb, D., 1997. The influence of dissolved organic carbon, suspended particulates, and hydrology on the concentration partitioning and variability of trace metals in two contrasting Wisconsin watersheds (U. S. A.). Chem. Geol. 136, 71-97.

Steiger, J., Gurnell, A.M., 2003. Spatial hydrogeomorphological influences on sediment and nutrient deposition in riparian zones: observations from the Garonne River, France. Geomorphology 49,1-23.

Steiger, J., James, M., Gazelle, F., 1998. Channelization and consequences on floodplain system functioning on the Garonne River, SW France. Regul. Rivers Res. Manag. 14, 13-23.

Teissier, S., Sauvage, S., Vervier, P., Garabétian, F., Sánchez-Pérez, J.-M., 2008. A massbalance approach to estimate in-stream processes in a large river. Hydrol. Process. 22, 420-428.

Tipping, E., 1994. WHAMC-A chemical equilibrium model and computer code for waters sediments, and soils incorporating a discrete site/electrostatic model of ion-binding by humic substances. Comput. Geosci. 20, 973-1023.

Tipping, E. Rieuwerts, J. Pan, G., Ashmore, M.R, Lofts, S., Hill, M.T.R., Farago, M.E. Thornton, I., 2003. The solid-solution partitioning of heavy metals ( $\mathrm{Cu}, \mathrm{Zn}, \mathrm{Cd}$, $\mathrm{Pb}$ ) in upland soils of England and Wales. Environ. Pollut. 125, 213-225.

Trancoso, A.R., Braunschweig, F., Chambel Leitão, P., Obermann, M., Neves, R., 2009 An advanced modelling tool for simulating complex river systems. Sci. Tota Environ. 407, 3004-3016.

Veyssy, E., Etcheber, H., Lin, R., Buat-Menard, P., Maneux, E., 1998. Seasonal variation and origin of particulate organic carbon in the lower Garonne River at La Reole (southwestern France). Hydrobiologia 391, 113-126.

Zarnetske,J.P., Gooseff, M.N., Brosten, T.R., Bradford, J.H., McNamara, J.P., Bowden, W.B. 2007. Transient storage as a function of geomorphology, discharge, and permafrost active layer conditions in Arctic tundra streams. Water Resour. Res. 43. 